\title{
Studying Nitric Oxide in the Developing Retina: Neuromodulatory Func- tions and Signaling Mechanisms
}

\author{
Renato Socodato ${ }^{1}$, Camila C. Portugal ${ }^{1}$, Thaísa G. Encarnação ${ }^{1}$, Ivan Domith ${ }^{1}$, Marcelo Cossenza ${ }^{1,3}$ \\ and Roberto Paes-de-Carvalho ${ }^{1,2, *}$ \\ ${ }^{1}$ Program of Neurosciences Department of Neurobiology Instituto de Biologia, Federal Fluminense University, Niterói, \\ RJ, Brazil \\ ${ }^{2}$ Department of Neurobiology, Instituto de Biologia, Caixa Postal 100180, Centro, Niterói, RJ 24001-970, Brasil \\ ${ }^{3}$ Department of Physiology and Pharmacology, Fluminense Federal University, Niterói, 100180, Brazil
}

\begin{abstract}
The retina is a highly organized structure responsible for transducing light stimulation into electrical responses. Retinal organization is conserved in all vertebrate species and the generation of retinal cell types is chronologically determined and fairly documented from amphibians to humans. Furthermore, the chick retina is a well-established experimental paradigm for neurochemical and developmental studies regarding the nervous system. Among many signaling molecules regulating retinal physiology, nitric oxide (NO) is likely to play a prominent role within the retina. NO is a gaseous signaling transmitter, which regulates a plethora of physiological functions within an organism, including high-order signaling events both in the developing and mature nervous system. In this review we focus on different aspects of NO signaling in regulating retinal cell neurochemistry, focusing mainly on developing chick retina as a prevalent experimental model. Based on literature and data gathered from our group we conclude that NO is a major atypical neurotransmitter in the retina, regulating signaling events associated with the development of embryonic retinal neurons and glial cells.
\end{abstract}

Keywords: AKT, AMPA, ascorbate, CREB, glutamate, L-arginine, PKG, SVCT2.

\section{THE CHICK EMBRYO RETINA AS AN EXQUI- SITE SYSTEM FOR NEUROCHEMICAL STUDIES}

The retina is a specialized tissue of the central nervous system (CNS), which is responsible for the reception and transduction of light stimuli derived from the outside environment. Within this tissue, the first processing of visual input takes place, which will be further processed in higher brain structures such as the optic tectum, thalamus and visual cortex. The cell types present in the retina are very well known and comprise the photoreceptors (rods and cones), horizontal, bipolar, amacrine and ganglion cells, as well as the Müller glial cells, and in some species interplexiform cells and the microglia. Most, if not all, neurotransmitter and neuromodulator molecules present in other areas of the CNS are also present in the retina, such as glutamate, dopamine, GABA, acetylcholine, adenosine, etc.

The avian retina, especially from Gallus gallus, is a very convenient model for neurochemical studies of the CNS because it is very easy to isolate during most of the embryonic period of development. Moreover, the neurogenesis in the chick retina is well known and the cells from the early developing tissue can be dissociated to prepare cultures where many of the neurochemical properties are maintained as in the intact tissue.

*Address correspondence to this author at the Departamento de Neurobiologia, Instituto de Biologia, Caixa Postal 100180, Centro, Niterói, RJ 24001970, Brasil; Tel: (55-21) 2629-2263; E-mail: robpaes@vm.uff.br

\subsection{Early Studies Using the Retina}

Acetylcholine was the first neurotransmitter identified in the chick retina [1] but a detailed study of chick retinal development and neurogenesis occurred in the 50 `s and 60 `s [2-4]. From this period are the pioneer studies from Moscona and collaborators who used the chicken retina to study the regulation of glutamine syntethase activity induced by corticoids [5-8].

Chick retinal cultures were developed and used in a variety of studies. Cultures of retinal cell aggregates were first developed $[9,10]$ and used to study glutamine synthethase induction and its dependence on cellular interactions [11,12]. Thereafter, different studies using distinct types of retinal cultures, including monolayer cultures showed the properties of GABA uptake and synthesis $[13,14]$. In the same period, other studies established the sequential appearance of neurons and the formation of synapses during chick retinal development $[15,16]$. The presence of receptors for neurotransmitters like acetylcholine, GABA and glutamate was detected in this tissue and studied during development [1719]. Dopamine-coupled cAMP production was studied during chick development and also in monolayer cultures $[20,21]$. Adenosine and different types of adenosine receptors, modulating adenylyl cyclase activity, were also detected in the developing chick retina [22,23]. Adenosine-elicited cAMP accumulation was detected in the chick retina since embryonic day 14, attaining a maximum effect at day 17 and 
decreasing in the post-hatching period [22]. On the other hand, dopamine-dependent cAMP accumulation, modulated by $\mathrm{A} 1$ adenosine receptors, was detected at earlier stages (E10) [24] and completely disappeared in the post-hatching period, although these receptors were detected by binding and could modulate the effect of forskolin at this period [25].

\subsection{Neurochemistry of the Chick Retina}

As specified above, many neurotransmitters and neuromodulatory molecules are expressed in the chick retina. Several groups studied the major excitatory and inhibitory neurotransmitters, respectively glutamate and GABA, in the intact chick retina as well as in cultures of chick retinal cells. Studies of GABA release as well as other amino acids and acetylcholine, induced by glutamate, highlighted the importance of this amino acid in retinal physiology $[26,27]$. Studies using purified cultures of chick retinal neurons showed the uptake of adenosine by neurons and photoreceptors as well as its release induced by membrane depolarization in a $\mathrm{Ca}^{2+}$-dependent manner [25]. Glutamate was also shown to induce the release of adenosine in chick retinal monolayer cultures [28]. Adenosine receptors were localized in the plexiform layers in the chick retina [29] and recent studies showed the regulation of A1 adenosine receptor expression by cell-cell contacts and activation of A2a adenosine receptors $[30,31]$.

\subsection{Why Study Nitric Oxide (NO) in the Retina?}

As stated by Garthwaite and Boulton, in a seminal review published in 1995, "the brain contains by far the highest activity of nitric oxide synthase (NOS) of any tissue so far examined, and the widespread distribution of the enzyme therein indicates that NO could be involved in practically all aspects of CNS function" [32]. Pioneer works established a clear linkage between NMDA-type glutamate receptors, NO and cGMP production in the CNS [33,34]. These studies were followed by the demonstration of NO production from L-arginine (L-Arg), NO-mediated activation of soluble guanylyl cyclase (sGC) [35] and the isolation and cloning of NOS [36-38]. An "explosion" of interest followed these findings and several groups described the localization and function of the machinery for NO production in diverse CNS regions, including the retina $[39,40]$. One important finding was that NADPH diaphorase, a histochemical marker used to label specific set of neurons, corresponded to NOS [41]. This was followed by studies showing the localization of NOS and citrulline in the brain and their colocalization with NADPH diaphorase [42]. Moreover, different authors have also shown the presence of NADPH diaphorase and NOS in the retina of several vertebrate species (further discussed in section 2).

We became very interested in studying the development of the NO system in the chick retina for several reasons. First, Gally and colleagues in 1990 proposed a hypothesis that NO could play an important role during development as a small and diffusible signal [43]. Other studies have shown that NMDA receptors and NO have important functions during cerebellum and motor neuron development [44-46]. Additionally, important studies demonstrated the effects of NO on growth cones and retinotectal projections [47, 48]. Still, the pioneering studies of Peunova and Enikolopov on the effects of NO on gene expression and cell cycle arrest during neuronal differentiation had a tremendous impact and opened a new field on cell signaling pathways activated by NO during nerve cell development [49-51].

\subsection{NO in the Developing Chick Retina: An Overview}

An extensive amount of literature arose since NO was elected the molecule of the year in 1992 [52]. After an amazing burst of research focusing in NO biology and chemistry in the CNS, our group was also seduced by the signaling of NO in the developing avian retina. However, to study the signaling events regulated by NO throughout the developing and mature CNS would require a very extensive review of the literature. Hereafter we will discuss data regarding signaling mechanisms of NO mainly in the chick, using findings from our group as the building blocks for further signaling roles within the retina. Inside the specific sections of this review, we will cover methodological advances for detecting and studying $\mathrm{NO}$ in the retina in a chronological point of view. Furthermore, a special emphasis will be given to the roles played by NO in the regulation of developmental aspects of embryonic retinal neuronal cells, such as neurotransmitter release, proliferation and cell death.

\section{DETECTING NO IN THE RETINA: THROUGH- OUT THE METHODOLOGICAL EVOLUTION}

\subsection{The Pale-Blue NOS}

The pioneer studies of Thomas and Pearce (1961) described a particular enzymatic activity known as NADPHdiaphorase in brain tissues. NADPH diaphorase can be detected by a histochemical technique based on the presence, in certain neurons, of an enzyme that catalyzed the NADPHdependent conversion of a soluble tetrazolium salt into an insoluble blue formazan precipitate [53]. In theory, any NADPH-requiring enzyme could exhibit diaphorase activity. However, when NADPH diaphorase histochemistry was applied to aldehyde-fixed brain tissues, only a specific population of neurons was stained [54]. This method was a useful tool for the examination of selective neuronal populations and was referred to be a selective marker for forebrain neurons containing specialized neurotransmitter systems (somatostatin, neuropeptide $\mathrm{Y}$ and cholinergic neurons) forming the ascending reticular system. Interestingly, cerebral NADPH-diaphorase activity remained a complete mystery until the early 90's, when Hope and colleagues (1991) showed that neuronal NADPH-diaphorase activity corresponds to NOS activity; henceforth, NADPH diaphorase histochemistry was employed as a specific histochemical marker for neurons producing NO.

In the late 90 `s, our lab became interested in relating the activity of NADPH-diaphorase with enzymatic NO production in the chicken embryo retina. Using the colorimetric property of formazan absorption, it was established that NADPH-diaphorase could be measured in retinal homogenates and its activity partially corresponded to NOS in the developing chick retina. The enzymatic activity could be measured within the early stages of retinal development (E8, E11 and E14), and was determined to be $\mathrm{Ca}^{2+}$-dependent. 
Indeed, the enzymatic activity increased 50\% in the presence of $\mathrm{Ca}^{2+}$ and was completely abolished by EGTA or EDTA $[55,56]$. Remarkably, $\mathrm{Ca}^{2+}$-dependent activation was reduced at E17 and became almost void in the post-hatching retina. When NADPH-diaphorase activity was measured in the presence of high concentrations of L-Arg analogs, around $35 \%$ of the activity remained, and this was related with the existence of other NADPH-dependent enzymes in normal retinal metabolism. Therefore, approximately $65 \%$ of NADPH-diaphorase activity was related to NOS and was predominant in early stages of retinal embryonic development [55]. Moreover, histochemical analysis revealed the presence of several stained cells over the whole extent of retinal tissue. At E12 and E14, stained cells were associated with photoreceptors, amacrine and ganglion cells. At E17, the staining was very similar to that found at post-hatching retinas, with a significant staining in the inner segments of photoreceptors and in few amacrine and ganglion cells. A similar staining pattern was previously observed for NADPH-diaphorase as well as NOS immunocytochemistry in retinas from other species, including rats [57-59], rabbits [60,61]and primates [62]. Although the staining appeared more intense in mature retinas, NADPH-diaphorase activity was approximately the same throughout development. However, the inhibition by L-Arg analogues was smaller in mature retinas, a fact that could indicate an increased presence of non-NOS NADPH-diaphorase in some cells at this stage.

\subsection{L-Citrulline: A Stoichiometric Partner for NO Pro- duction}

In 1982, Deguchi and Yoshiokag showed for the first time that L-Arg was an endogenous activator of soluble guanylyl cyclase (sGC) in neuroblastoma cells [63]. Indeed, in the late 70's, Murad and his associates demonstrated that several nitroso compounds could stimulate sGC activity, causing an increase in cGMP accumulation [64,65]. As a sequence of these fundamental studies, Moncada's group showed that sGC stimulation by L-Arg (as previously proposed by Deguchi and Yoshiokag, 1982) precisely matched L-Citrulline (L-Cit) formation in the CNS, with a concomitant NADPH and $\mathrm{Ca}^{2+}$-dependence. Hence, L-Cit produced in the CNS was in fact a stoichiometric co-product of NO synthesis catalyzed by NOS [35]. Interestingly, nerve tissues exhibit L-Cit formation despite the absence of ornithine carbamoyltransferase (OCT) and carbamoyl phosphate syntethase I (CPS-I) expression, two important enzymes involved in the urea cycle [66]. Therefore, all L-Cit formed in the CNS was strongly associated with NOS activity and NO production [67].

Besides the NADPH-diaphorase histochemical localization and biochemical determination by the formazan absorption assay, we were motivated to find alternative methodologies which could detect NO formation. We then started to use a series of scintillation-based spectrophotometric methods to evaluate the conversion of L- $\left[{ }^{3} \mathrm{H}\right]$-Arg into L- $\left[{ }^{3} \mathrm{H}\right]$-Cit as an indicative of NOS activity. We initially used a Dowex AG50-WX8 resin packed into a chromatographic column to separate L- $\left[{ }^{3} \mathrm{H}\right]$-Cit from L- $\left[{ }^{3} \mathrm{H}\right]$-Arg in experiments employing homogenates from the retina. Our lab, and Macaione's group, concomitantly showed that NOS activity was high at earlier stages of retinal development (E8 and E9), decreasing until E13-14 and attaining minimal levels at E15 up to the post-hatching period $[55,68]$. At that time, experiments using retinal homogenates were instructive in providing details regarding NOS enzymatic activity during development, $\mathrm{Ca}^{2+} / \mathrm{CaM}$ dependence and relative efficacy for different inhibitors [69]. To better evaluate the contribution of some signaling systems involved in NO generation, we developed a precise chemical analysis based on thin layer chromatography and scintillation [40]. Protein-free samples either of extracellular or intracellular medium was added to silica gel plates, together with a standard solution containing L-Arg, L-ornithine (L-Orn) and L-Cit [70]. A mixture of chloroform, methanol and ammonium hydroxide (2:3:2; v/v/v) was used as an eluent. For the determination of retention factors (Rfs), we sprinkled a solution containing ninhidrin $(0.1 \%$ ethanol/acetic acid, 5:1; v/v). The Rfs appeared at different spots (L-Arg, 0.20; L-Orn, 0.40; L-Cit, 0.69) and silica areas containing the selected amino acids were scraped off from plates for radioactivity determination by liquid scintillation (hereafter we refer to this entire process as TLC analysis). With this procedure, we measured L- $\left[{ }^{3} \mathrm{H}\right]$-Cit formation and associated it with NOS activity [70]. Moreover, we verified the amounts of L- $\left[{ }^{3} \mathrm{H}\right]$-Arg and $\mathrm{L}-\left[{ }^{3} \mathrm{H}\right]$-Cit present in retinal cells, as well as in the extracellular fraction. At the same period, we were also interested in evaluating L- $\left[{ }^{3} \mathrm{H}\right]$-Arg uptake in neuronal and glial cells and in determining the cellular target related with L-Cit/L-Arg mobilization. For such, we performed L- $\left[{ }^{3} \mathrm{H}\right]$-Arg autoradiography and visualized a high density of autoradiographic grains in cultured glial cells [70]. We noticed that the labeling was weak in neurons, especially in the ones close to or above glial cells. Interestingly, retinal neurons, including photoreceptors, exhibited an extensive labeling when grown in the absence of glial cells [70]. These observations suggested that glial cells could take up L-Arg with high affinity and promptly release it to neurons. To test this hypothesis, we used purified glial cell cultures pre-loaded with L- $\left[{ }^{3} \mathrm{H}\right]$-Arg. Then, coverslips containing purified neurons were transferred to dishes containing the radiolabeled glial cells and accommodated onto a plastic apparatus, which avoided the direct contact between the two cellular populations but allowed medium sharing. Using this procedure we demonstrated that glial cells released $\mathrm{L}-\left[{ }^{3} \mathrm{H}\right]-$ Arg in response to depolarization induced by high potassium. When released material was analyzed by TLC, most of the radioactivity was found as L-Arg, with smaller amounts of L-Orn and L-Cit, indicating that glial cells were capable of retaining and releasing L-Arg that could be taken up by neurons [70]. Using a similar methodological approach, Bolaños group showed that rat astrocytes could release L- $\left[{ }^{3} \mathrm{H}\right]-$ Arg, which could be taken up by neurons upon peroxynitrite $\left(\mathrm{ONOO}^{-}\right)$treatment [71]. These findings indicated an interesting mechanism for the regulation of neuronal NO production, since the enzymatic activity of NOS with low availability of L-Arg leads to $\mathrm{O}_{2}^{-}$production. This reactive oxygen species, in the presence of residual NO, gives rise to ONOO', which in turn would be the trigger for glial L-Arg supply [71]. Prior to that, Grima and colleagues demonstrated that 
the stimulation of non-NMDA receptors promoted L-Arg release from rat astroglial cultures [72,73].

At that time, it was clear that both neuronal and glial cells could take up L- $\left[{ }^{3} \mathrm{H}\right]$-Arg, but glial cells appeared to regulate the demand for neuronal L-Arg uptake. Since L-Arg is an important amino acid present in proteins, we decided to use the protein synthesis inhibitor cyclohexymide (CHX) during uptake assays to avoid the protein synthesisdependent component in L-Arg uptake [23]. Interestingly, we demonstrated that protein synthesis represented an important driving force for L-Arg uptake [23]. More than 70\% of intracellular taken up L-Arg was incorporated into proteins and when this incorporation was blocked by CHX, the free intracellular L-Arg pool increased significantly. Unexpectedly, when protein synthesis was inhibited, the intracellular L-Cit production increased and the extracellular content of L-Cit increased even more [23]. This particular phenomenon drew our attention to two facts: (1) High levels of L-Cit found in the extracellular environment could be related with some releasing system working in concert with intercellular recycling pathways. Indeed, glial cells express the enzymes involved in the de novo formation of L-Arg by transamination (ASS and ASL) [74-77]. (2) Protein synthesis could play an active role as an intermediate step between L-Arg influx and the control of its intracellular availability for NO synthesis. Actually, we found that activation of NMDA receptors increased $\mathrm{L}-\left[{ }^{3} \mathrm{H}\right]$-Cit formation, but it also inhibited protein synthesis and increased intracellular free L-Arg. Moreover, these effects were mediated by $\mathrm{Ca}^{2+} / \mathrm{CaM}$-dependent activation of the enzyme eukaryotic elongation factor 2 kinase (eEF2K). In such way, stimulation of NMDA receptors would be the trigger not only for NOS enhanced activity, but also for increased L-Arg availability produced by inhibiting protein synthesis [23].

\subsection{Painting NO with Antibodies}

Later on, we decided to look for the cell type that could produce NO in retinal cultures. At the late 90's, Dr. S. Vincent from the University of British Columbia in Canada kindly supplied antibodies against L-Cit which were tested extensively, and its colocalization with NOS was determined in several structures throughout the CNS [78]. Using avidinbiotin-peroxidase complex with a diaminobenzidinedeveloped staining, we visualized a large proportion of neurons, including photoreceptors, which were immunolabeled, with no staining observed in glial cells. The immunoreactivity for L-Cit was greatly reduced when cultures were preincubated with the NOS inhibitor L-nitroarginine (L-NA). Moreover, using antibodies against neuronal NOS, we observed the same labeling pattern in neuronal cells, while glial cells were devoid of staining. The antibodies against neuronal NOS were kindly supplied by Dr. V. Riveros-Moreno (Wellcome Research Laboratories, Beckenham, Kent, U.K.). This antibody was raised against the sequence 519-540 (LPLLLQANGNDPELFQIPPELC) of the rat neuronal enzyme. Despite being produced for rat NOS, the antibody worked perfectly in our cellular model (the chick retina). Therefore, based on our experimental data we suggested that, in the retina, most of the NO synthesis constitutively occurs in neurons but not in glial cells. Nonetheless, under special circumstances, retinal glial cells also produce NO (further discussed in the next section).

\subsection{NO More Mysteries with the Griess Method}

When Johann Peter Griess in 1879 described an analytical detection method for nitrite $\left(\mathrm{NO}_{2}{ }^{-}\right)$, he could never have guessed it would be one of the most propagated methods in experimental biology [79]. NO, as it is now known, oxidizes quickly in biological environments producing $\mathrm{NO}_{2}{ }^{-}$and $\mathrm{NO}_{3}$, which in the past was "invisible" in several experimental protocols. For more than a century, the Griess reaction has been used analytically to identify $\mathrm{NO}_{2}^{-}$produced by bacterial reduction of $\mathrm{NO}_{3}{ }^{-}$. This procedure was related with the diagnosis of bacterial infection in the urogenital tract [80].

The Griess reaction is inexpensive and marked by its experimental simplicity. Since this reaction is specific for $\mathrm{NO}_{2}{ }^{-}$, the analysis of the final oxidized product $\mathrm{NO}_{3}{ }^{-}$requires either chemical or enzymatic reduction for its determination. The procedure consists of a diazotization reaction using $\mathrm{NO}_{2}{ }^{-}$ (II) and sulfanilic acid (I) to form a diazonium cation (III) under acidic conditions. After cation formation, an aromatic electrophilic addition reaction occurs with aromatic amine (IV) to produce water-soluble azo dye (V), according to the following scheme:

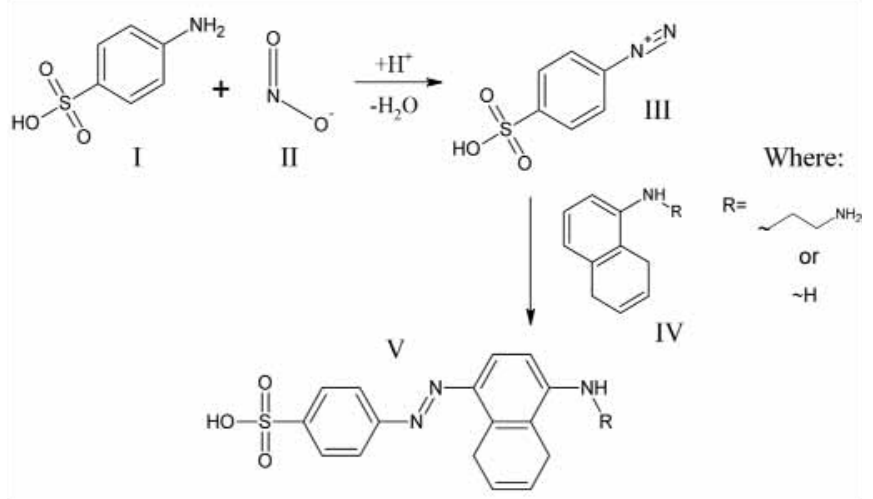

Nowadays, it is known several variations of this method and every laboratory in different areas use their own adapted Griess assay [80]. In that sense, we decided to use a copperplated cadmium reduction, as described by Green and colleagues (1982) [81,52,48], with modifications [82,53,49]. Briefly, samples were deproteinized with zinc sulfate $\left(\mathrm{ZnSO}_{4}\right)$ and $\mathrm{NaOH}$, reduced with activated cadmium by copper sulfate $\left(\mathrm{CuSO}_{4}\right)$ and the nitrite content measured with the Griess reagent. We used this technique in studies showing that NO displays a neuroprotective effect in the chick embryo retina. We demonstrated that re-feeding purified neuronal cultures with fresh medium caused intense cell death (further discussed in section 3), an effect blocked by pre-treatment of cultures with adenosine and activation of A2a receptors [83]. We explored the mechanism by which NO, produced from the NO donor S-nitroso-acetyl-D-Lpenicillamine (SNAP), showed a similar neuroprotective effect in such experimental paradigm. Our measurements of $\mathrm{NO}_{2}^{-}$production showed that NO release from SNAP is complete after $3 \mathrm{~h}$ either in the presence or absence of cells and nitrite production is linear as a function of SNAP concentration. Interestingly, SNAP not only reduced the neu- 
ronal death promoted by re-feeding but also produced an increase in neurite outgrowth [84].

In a different work, Socodato and colleagues [114] used a selective NO sensor to detect the release of NO in cultured retinal cells stimulated with glutamate. Interestingly, it has been demonstrated that the recovery of $\mathrm{NO}$ from $\mathrm{NO}_{2}{ }^{-}$using iodide was possible. The authors took advantage of this chemical property and performed this transformation, according to the following scheme.

$$
2 \mathrm{NO}_{2}^{-}+2 \mathrm{I}^{-}+4 \mathrm{H}^{+} \longrightarrow 2 \mathrm{NO}+\mathrm{I}_{2}+2 \mathrm{H}_{2} \mathrm{O}
$$

Moreover, this chemical reaction shows the mole conversion of $\mathrm{NO}_{2}^{-}$to $\mathrm{NO}$ with a 1:1 ratio and thus a very reliable quantification of released $\mathrm{NO}$ content in our culture samples could be resolved either under non-stimulated or stimulated conditions. This work showed that NO was quickly generated in cultured retinal neurons when those cells were stimulated by glutamate [114]. Taking into account previous immunocytochemistry data from L-Cit labeling, where only neurons were stained [70], Socodato and cols [114] demonstrated that cultured Müller glial cells could not release NO, even when stimulated with glutamate. Therefore, we strongly suggested that in retinal tissues there is an important endogenous nitrergic activity and that neuronal-glial interplay directly modulates bioavailability of the NOS substrate (L-Arg) for NO production and release in early-developing retinal neurons (Fig. 3).

\subsection{The Shining DAF}

Kojima and colleagues (1998) proposed a very innovative way for determining NO content within a cell. For the first time it was available a specific NO-trapping tool with the possibility of tracking and visualizing intracellular NO with temporal and spatial resolution. The authors synthesized a series of diaminofluoresceins (DAFs), which displayed high selectivity for NO, differently from previous 2,7dichlrofluorescein that could react with different ROS, including NO. The main characteristic of DAF-based compounds is that they present aromatic vicinal diamines, which are capable of reacting with NO in the presence of oxygen, forming a triazolic ring that expands its conjugating boundsystem, thus absorbing blue light at $495 \mathrm{~nm}$ and emitting fluorescence at $515 \mathrm{~nm}$ [85]. In such way, the substance that produced better results regarding fluorescence stability and $\mathrm{pH}$ range was diacetate DAF-2 (DAF-2 DA), which has two additional ester bounds in a two-phenolic ring. It is well known however that intracellular environments display high esterase activity and promotes the hydrolysis of ester bounds to create esterate anionic compounds. Those compounds therefore present a strong anionic characteristic and are likely to be trapped within a cell upon hydrolysis. Kojima and colleagues (1998) demonstrated that NO could be fairly quantified and visualized in biological samples using DAF-2 DA. Subsequently, the same group demonstrated that DAF-2 fluorescence stability could be improved towards a broader $\mathrm{pH}$ range by the addition of a methyl group in a triazoleforming amine and two fluor atoms in the vicinal acetate groups [86]. The synthesized substance was named diacetate difluormethyl DAF (DAF-FM-DA), and had a widespread use in different cellular systems, including in cultured neuronal cells (Fig. 1).

Using the quantitative characteristics of DAF-FM-DA fluorescence in cultured retinal neurons, Socodato and colleagues demonstrated that activation of glutamate receptors could strongly increase DAF-FM-DA fluorescence intensity

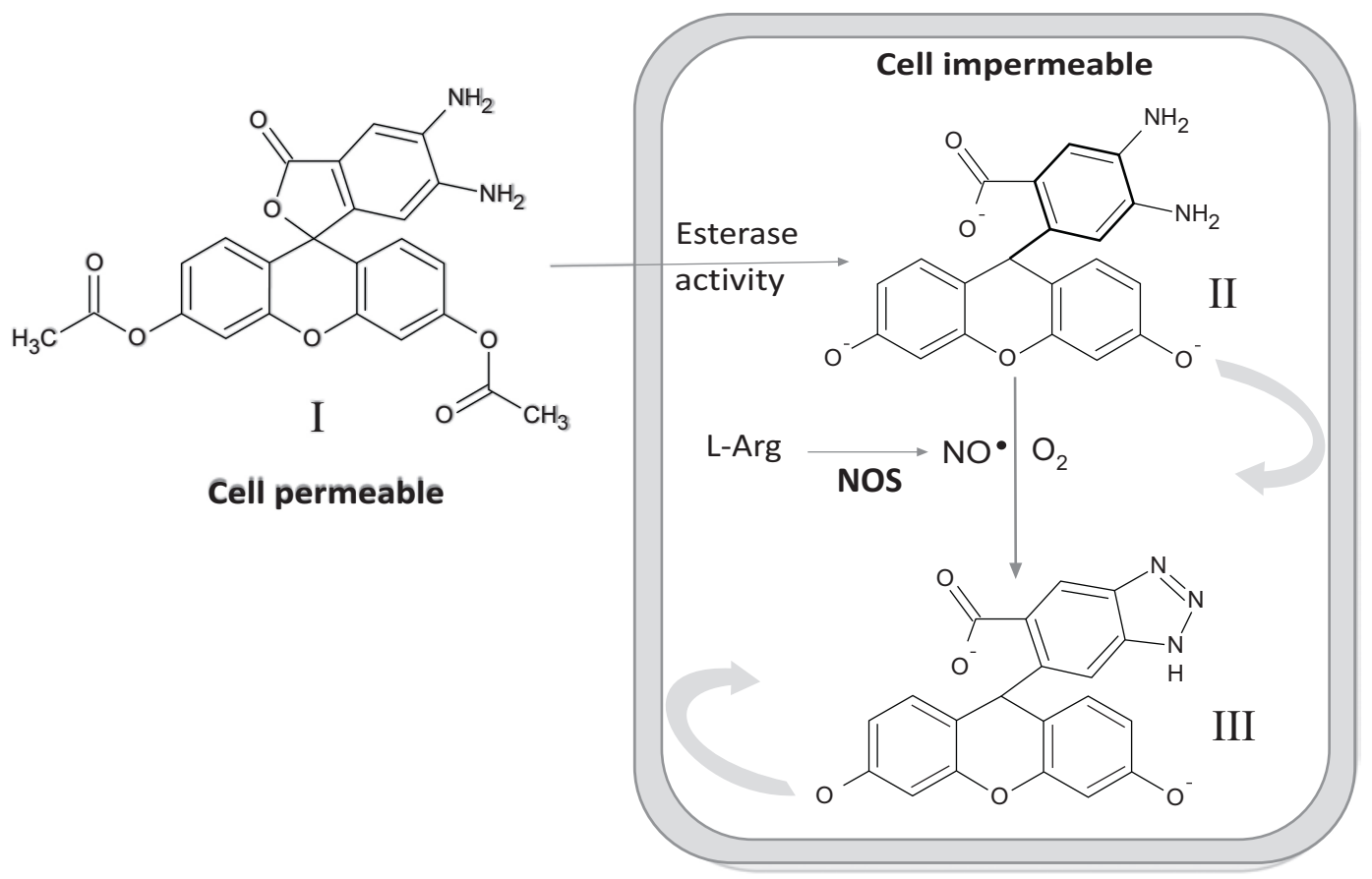

Fig. (1). Schematic representation of DAF-FM-DA action mechanism. DAF-FM-DA is a lipophilic permeable compound (I) that is hydrolyzed by intracellular esterases. Since the anionic form (II) is trapped within the cell, the newly NO produced could immediately react with the aromatic vicinal diamines forming a triazolic ring. This newly formed compound (III) could be detected by fluorescence methods. 
[87]. Moreover, the authors specifically showed that neuronal stimulation of $\mathrm{Ca}^{2+}$-permeable AMPA receptors was the initial trigger for the activation of nNOS and NO production [87]. Different from indirect NO measurements and LCit immunostaining, the remarkable feature of using DAFFM-DA was that we could observe that although NO was exclusively produced in neurons, it could also be found in the Müller glia (Fig. 2). This finding definitely demonstrated the existence of glial targets, modulated by neuronal-derived NO, as suggested by previous data from our group (Fig. 3). So, we were ultimately convinced that NO neurochemistry depended on both cell types in the developing retina: neurons (producers) and Müller glial cells (substrate suppliers).

\section{NO SIGNALING AND DEVELOPMENT: FOCUS- ING IN THE EMBRYONIC RETINA.}

3.1. NO and the Release of Neuromodulators in the Retina

Nitric oxide is an important molecule, which regulates the release of several neuromodulators in the chick retina, such as GABA, glutamate, glutamine, ascorbate and others [88-90].

\subsubsection{GABA and Glutamate}

Ientile and colleagues showed that NMDA receptor stimulation was capable of stimulating glutamate, GABA and glutamine release in the retina [88, 91]. It has also been observed that the NMDA effect on the release of neuro- modulators was NO-dependent since L-NA, a selective NOS inhibitor, totally blocked the NMDA effect in the E9 chick retina [88]. To corroborate this finding, two other NO donors were used, sodium nitroprusside (SNP) and SNAP, and both increased GABA, glutamate and glutamine release. Important data documented in the 1996 article by Ientile and colleagues was the demonstration that NMDA effect was not potentiated by zaprinast, a cGMP phosphodiesterase inhibitor, thus suggesting that the canonical pathway is not involved in the NMDA effect. Furthermore, 8-Br-cGMP, a membrane permeable and phosphodiesterase-resistant cGMP analogue, could not induce GABA, glutamate or glutamine release. The authors showed that this NO-induced GABA and glutamate release occurred before the period of synaptogenesis and they suggested that these phenomena might contribute to important functions during retinal development [88].

In a different experimental model, using the paradigm disseminated by the group of de Mello [92], Ientile and colleagues [91] in 1997 tested GABA release in cultured retinal cells. In this work, they showed that NMDA promoted an increase in $\left[{ }^{3} \mathrm{H}\right]$-GABA release and that this effect was mediated by NO, since it was blocked by L-NA and mimicked by the NO donor spermine/NO complex (SpNO). On the other hand, the authors documented that the NMDA effect depended on cGMP, since 8-Br-cGMP mimicked this NOinduced GABA release, and zaprinast amplified both NMDA and SpNO-mediated GABA release [91]. The discrepancy between these two studies (from 1996 and 1997) could be
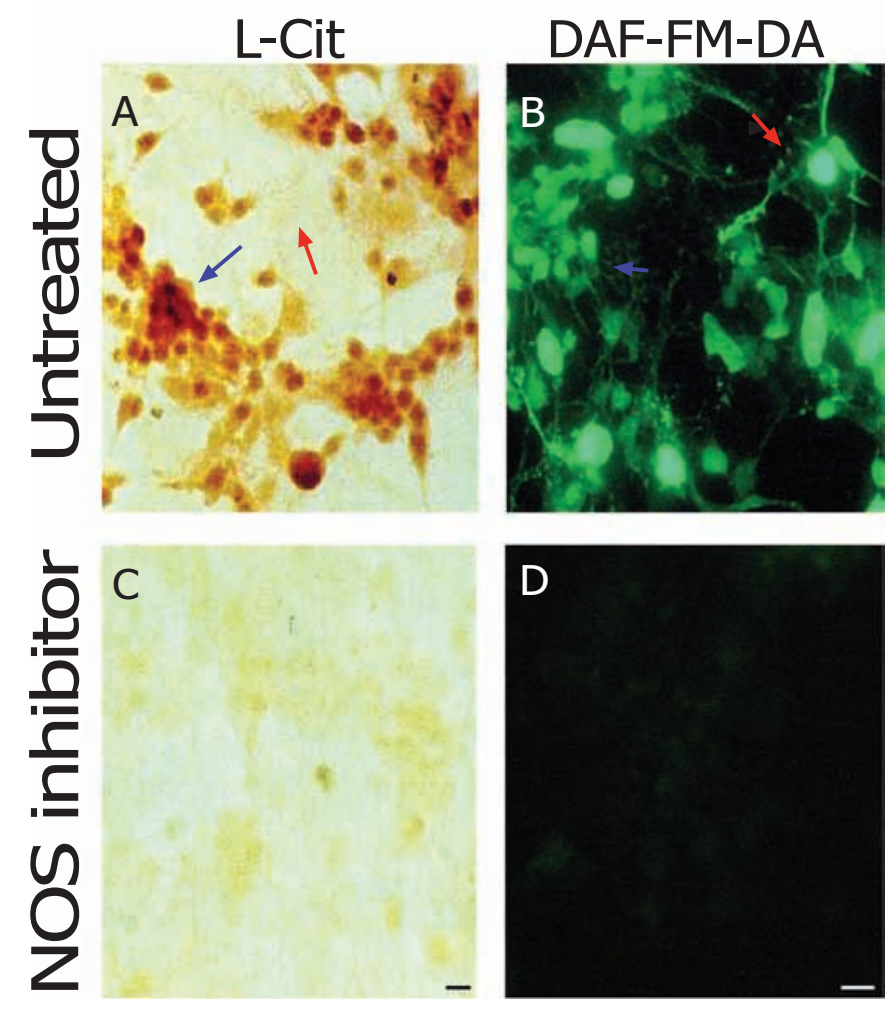

Fig. (2). Determination and cellular localization of NO in embryonic chick retinal cultures. The left photomicrographs (A and C) represent the immunocytochemistry for L-citrulline using diaminobenzidine. The right photomicrographs (B and $\mathbf{D})$ represents the triazolic compound fluorescence formed by NO and DAF-FM-DA reaction. Note the L-citrulline immunostaining in neurons (blue arrows) and total absence of this staining in glial cells (red arrows). The DAF-fluorescence was also verified in neurons and unexpectedly in glial cells. The labeling was totally prevented by NOS inhibitors (L-NA 500 $\mathrm{M}$ in C; 7-NI $200 \mu \mathrm{M}$ in D). Scale bar $10 \mu \mathrm{m}$. 


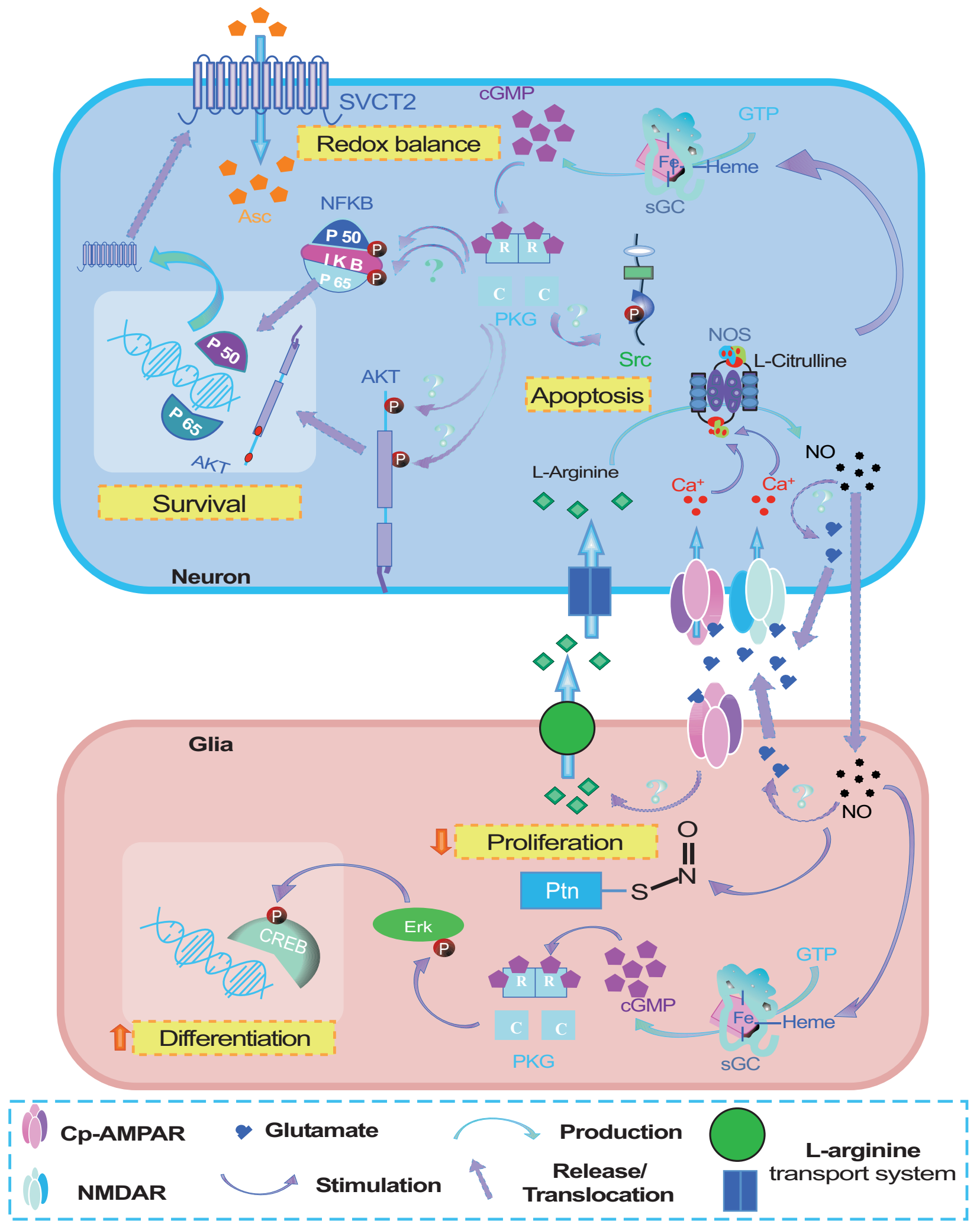

Fig. (3). Schematic representation of multiple NO pathways described throughout this review.

explained by the use of different experimental models, and the authors suggested that the chick retina cell culture was a more suitable model than acute retinal segments for the characterization of neurochemical processes related with retinal development and differentiation [91].
In line with this, it was later shown that NO could also stimulate GABA release in a different experimental model, the adult turtle retina [93]. The authors observed that the NO effect was cGMP-dependent. Another important finding described in that work was the mechanism by which the NO 
donor DETA NONOate could stimulate GABA release. It was demonstrated that DETA NONOate-induced GABA release was mediated by the reversal of GABA transporters (GAT) in horizontal cells, which depended on $\mathrm{Ca}^{2+}$ ions in the inner plexiform layer [93].

Regarding GABA release, an opposite finding was described [89]. The authors demonstrated that NO inhibited GABA release in the post-hatched chick retina in a $\mathrm{Ca}^{2+}$ independent and $\mathrm{Na}^{+}$-dependent fashion by the reversal of GAT. This finding was corroborated by experiments utilizing NO-711, a GAT inhibitor [89]. Besides the animal model, a significant difference between these works was that Maggesissi et al. (2009) treated chicken retinas with L-Arg while Yu and Eldred (2005) used DETA NONOate, a NO donor, in the turtle retina. Accordingly, the differences between these studies could be explained by the differences between NO bioavailability generated by L-Arg and DETA NONOate within the retinas. It was observed that L-Arg exerted a biphasic modulation in the ganglion cell layer, as low concentrations of NO led to inhibition of GABA release whilst high NO concentrations increased GABA release. On the contrary, in amacrine cells, NO could only inhibit GABA release regardless the concentration used [89].

\subsubsection{Glycine}

NO is also capable of regulating the transport of glycine, another inhibitory retinal neuromodulator [93,94]. It was first observed, in rabbit retinas, that NO donors (SNP and SNAP) inhibited high potassium-mediated glycine release [94]. Additionally, it was observed in the adult turtle retina that DETA NONOate could enhance glycine uptake and inhibit its release. To better evaluate this NO effect, $\mathrm{Yu}$ and Eldred used 8-Br-cGMP and SIN-1, a ONOO ${ }^{-}$donor, and observed that SIN-1, but not 8-Br-cGMP, mimicked DETA NONOate effect, suggesting therefore that NO may work through $\mathrm{ONOO}^{-}$to stimulate glycine uptake and inhibit its release [93]. In summary, different groups showed that NO is capable of modulating the release of inhibitory neurotransmitters in many retinal cell types and at different developmental stages of the vertebrate retina.

\subsubsection{Acetylcholine}

$\mathrm{NO}$ is also capable of regulating the release of other retinal modulators such as the stimulatory neurotransmitters acetylcholine [94,95] and dopamine [96-98].

Regarding acetylcholine release, it was described in the rabbit retina that NO donors (SNP and SNAP) enhanced its release induced by high potassium and flickering light. Likewise, the NOS inhibitors, L-nitromonomethylarginine (L-NMMA) and L-NA, reduced light-evoked acetylcholine release. Moreover, as the NO effect was inhibited by strychnine, it was postulated that the increase of acetylcholine release was indirectly mediated by the inhibition in glycine release [94].

In line with this, Okada and colleagues (2001) demonstrated that NO regulates acetylcholine release in the isolated rat retina. Nonetheless, they observed that NO donors (SNAP and NOR3) inhibited high potassium evokedacetylcholine release [95]. This inhibition seemed to be mediated specifically by NO since carboxy-PTIO (a NO scav- enger) abolished SNAP-induced inhibition of KCl-evoked acetylcholine release. Additionally, bicuculline, a $\mathrm{GABA}_{\mathrm{A}}$ receptor antagonist, abolished the effect of $\mathrm{NO}$ on $\mathrm{KCl}-$ mediated release, suggesting that $\mathrm{NO}$ potentiates GABA efflux leading to the concomitant inhibition of acetylcholine release [95]. Taken together, these findings strongly suggest that acetylcholine release is related with regulatory effects mediated by NO upon the bioavailability of inhibitory neurotransmitters, as accessed either by their uptake or release from neuronal cells.

\subsubsection{Dopamine}

Regarding dopamine release, it was observed in the intact bovine retina that a NO donor, hydroxylamine, decreased both basal and potassium-induced dopamine release [96]. In the same report, Bugnon and colleagues also tested whether the NO effect was mediated by cGMP. In order to answer this question, dibutyryl cGMP was used and it was ineffective, suggesting therefore that endogenous NO regulates dopamine release by a cGMP-independent mechanism.

In agreement with Bugnon and colleagues, it was demonstrated that NO leads to a striking decrease in dopamine release stimulated by high potassium in the rabbit retina [97]. In this work, three NO donors were tested (hydroxylamine, SNP and SNAP), and all of them displayed the same effect, i.e. the inhibition of dopamine release. Djamgoz and colleagues in 1995 [99] also evaluated the possible participation of GABA in this NO effect. Likewise, they observed that bicuculline had no significant effect on dopamine release, suggesting that NO had a direct signaling role upon dopaminergic cells. The same group also reported that the decrease in dopamine release observed was not related to SNPmediated dopamine oxidation at the extracellular environment [99].

Likewise, Pottek and colleagues in 1997 observed in intact carp retinas that SNP did not interfere with basal dopamine levels but could prevent high potassium-evoked dopamine release [98]. In summary, it was demonstrated, in different animal models (bovine, rabbit and carp), that NO inhibits dopamine release mediated by depolarizing stimulus in retinal cells. Additionally, this NO modulation of dopamine release could represent a high-order function in the process of light transduction within the retina since dopamine is a putative transmitter associated with light adaptation.

\subsubsection{Ascorbate}

Our group described for the first time that NO was capable of stimulating ascorbate uptake in cultured chick retinal cells [90]. Since the early 90's, ascorbate was claimed as an important molecule in the CNS acting as a neuromodulator [100]. Additionally, ascorbate has been described as an important factor for glutamatergic neuronal maturation in the brain [101]. Ascorbate has been shown to be present in a variety of vertebrate retinas [102, 103], including the chick retina [103]. In this tissue, ascorbate displays many functional roles such as: (1) prevention of dopamine oxidation; (2) prolongation of dopamine actions in the extracellular environment [99]; (3) regulation of voltage-dependent potassium currents in ON-centered mixed bipolar cells [104]; and (4) inhibition of dark-induced GABA efflux [105]. In line with this, high-affinity proteins called sodium vitamin $\mathrm{C}$ co- 
transporters (SVCTs) stereospecifically transport ascorbate in a $\mathrm{Na}^{+}$-dependent manner using two $\mathrm{Na}^{+}$ions for each transported ascorbate molecule [106, 107]. Previous studies showed the presence of SVCT-2 transcripts in the inner nuclear layer of the rat retina [107] and our group demonstrated the presence of SVCT-2 in both cultured chick retinal cells and post-hatched chick retina [90, 108].

Regarding the importance of ascorbate and NO to retinal physiology, our group tested the effect of NO donors (SNAP and Noc-5) and L-Arg on ascorbate uptake and observed that these compounds could stimulate the uptake of ascorbate in cultured retinal cells [90]. In order to confirm the participation of NO, the scavenger carboxy-PTIO was tested and it completely blocked the effect of SNAP. Moreover, we evaluated whether the classical NO pathway could stimulate ascorbate uptake. In such way, we treated cultured retinal cells with sGC and PKG inhibitors and observed that these compounds completely blocked NO-stimulated ascorbate uptake [90]. Additionally, we performed a kinetic characterization of this effect and observed that $\mathrm{NO}$ increased the $\mathrm{V}_{\max }$ for ascorbate uptake, suggesting that it modulates the SVCT2 transport capacity. This increase in transport capacity induced by NO could reflect an increase in SVCT-2 expression. To test this hypothesis we performed qRT-PCR, western blotting and immunocytochemistry and observed that NO augmented SVCT-2 transcription and expression via its classical sGC/cGMP/PKG pathway [90].

As we observed an increase in SVCT-2 mRNA, we decided to evaluate SVCT-2 synthesis. It has already been described that the transcription factor NF- $\mathrm{kB}$ was capable of modulating SVCT-2 expression [109]. We then tested whether this transcription factor was involved in NOinduced SVCT-2 expression and observed that NF- $\mathrm{kB}$ inhibitors (PDTC and sulfasalazine) completely blocked NO or L-Arg-induced SVCT-2 expression and ascorbate uptake. These data suggested that NO positively regulates SVCT-2 expression and this enhanced expression modulates ascorbate uptake in cultured retinal cells [90] (Fig. 3). In order to verify whether this effect only occurred in cultured cells, we used the intact chick retina and observed that SNAP or LArg robustly increased SVCT-2 expression and ascorbate uptake, indicating that NO-induced stimulation of SVCT-2 expression and ascorbate uptake also occurs in vivo.

Overall, within this whole section, it was reported that NO regulates the increase or decrease in evoked and endogenous release of neurotransmitters, probably profoundly impacting on retinal physiology and promoting drastic effects on visual responses. Moreover, considering the entire panel of NO actions within the developing retina, one can conclude that NO-regulated transmitter release directly impacts on the development of retinal cells.

\subsection{NO and Proliferation of Developing Retinal Cells}

Our group demonstrated in 2006 that NO donors such as the S-nitrosothiol SNAP and SpNO were capable of inhibiting $\left[{ }^{3} \mathrm{H}\right]$ thymidine incorporation in retinal cells [110]. In those experiments, we took advantage of the high proliferation rate of embryonic retinal cells in culture to evaluate radiolabeled thymidine incorporation into the DNA as a direct index of mitotic progression. The data clearly showed that
SNAP and SpNO decreased thymidine incorporation in cultured retinal cells and in the in vivo embryonic retina. Those drugs, on the other hand, were not effective in increasing retinal cell death. Differently from data where NO was released from NO donors, blockade of basal NOS activity by a broad spectrum NOS inhibitor (L-NA in that case) had no significant effect in diminishing thymidine incorporation in retinal cultures [110], which was suggestive that endogenous NO production played no significant role in regulating the proliferation of cultured retinal cells.

Seminal works relating NO with nerve cell proliferation [51] and fly development [49] have clearly established that in developing neurons, throughout the embryonic CNS, NO signals to induce cell cycle arrest. Data gathered up to 2006, however, did not convey the embryonic retina as a working model for the anti-proliferative effects of NO. Furthermore, although NO usually stimulates sGC to produce cGMP, this NO-induced proliferation arrest in retinal cells was independent of this canonical pathway [110]. In the same study, Magalhães and colleagues demonstrated that this decrease of NO-induced thymidine incorporation was neither inhibited by ODQ (a blocker of sGC) nor mimicked by cGMP analogs, but was completely blocked by the anti-oxidant DTT, suggesting that S-nitrosylation was operative in regulating the decrease of NO-mediated proliferation in developing retinal cells. Ientile and colleagues demonstrated that NO donors such as SNAP and SNP promoted glutamate, GABA and glutamine release from cultured embryonic retinal neurons in a way independent of cGMP accumulation. Although data from Ientile et al. was not directly related with retinal proliferation, they demonstrated a NO-dependent and cGMP-independent release of important neurotransmitter molecules for retinal physiology. On the other hand, it was recently shown that NO was capable of enhancing the proliferation rate of endothelial cells through an S-nitrosylationdependent mechanism [111].

An attractive hypothesis presented in the paper of Magalhães et al. [110] was that NO-mediated inhibition of retinal cell proliferation was associated with the capacity of $\mathrm{NO}$ to S-nitrosylate ornithine decarboxylase (ODC) to consequently decrease polyamine synthesis. This premise took into account an earlier finding by the group of Ignarro [112] showing that NO donors, including S-nitrosoglutathione (GSNO), inhibited the activity of purified ODC and this effect was prevented by DTT (as in the paper of Magalhães et al. [110]) or glutathione. However, Magalhães and colleagues found no evidence of ODC inhibition, since an ODC blocker could not reproduce the SNAP effect in decreasing retinal cell proliferation.

Besides inhibiting retinal cell proliferation, it was also observed that SNAP could block the increase of ATPinduced proliferation in the retina [110], which in turn was MAP kinase-dependent [113]. However, inhibition of cell proliferation induced by NO did not involve an upstream inhibition of the MAPK pathway, since SNAP strongly increased ERK phosphorylation [110]. In later studies, Socodato and colleagues (2009 and 2012) explored these phenomena and demonstrated that NO regulates ERK pathway through the cGMP/PKG/Src signaling network (discussed in the next sub-session). 
The main contribution in the work carried out by Magalhães and colleagues in 2006 was the elegant demonstration that glial cells, but not neurons, were the main in vitro targets of NO (Fig. 3). Using thymidine incorporation coupled to image-based autoradiography, the authors showed that cultured Müller glial cells were densely labeled within the nuclei with autoradiographic grains in control groups. Importantly, SNAP-treated cells were completely devoid of this labeling pattern, indicating that NO inhibited Müller glial cell proliferation.

\subsection{NO and Transcription Factor Activation: CREB as a Model in the Retina}

In a different work, our group showed that glutamate could induce a transitory ERK2 phosphorylation through the activation of AMPA/Kainate ionotropic glutamate receptors [114]. These data were supported by findings showing that DNQX, an AMPA/Kainate receptor antagonist, but not MK801, an NMDA receptor blocker, suppressed this glutamateinduced ERK2 phosphorylation [114]. Interestingly, the glutamate effect was completely abrogated by nNOS inhibition. Therefore, this evidence suggested that ERK2 phosphorylation induced by AMPA/Kainate receptors was indeed coupled to NO production, pointing toward a direct interaction between these receptors and nNOS [114]. Later on, we managed to demonstrate that this nNOS-mediated NO increase involved the activation of $\mathrm{Ca} 2+$-permeable AMPA receptors in retinal neurons [87].

Differently from Magalhães et al. (2006) data, NOinduced ERK2 phosphorylation relied exclusively on the canonical NO pathway [114]. Again, pharmacologically mapping the classical NO pathway showed that sGC activity, cGMP accumulation, PKG modulation and PKG-induced Src activation were the main signaling events involved in glutamate and NO-induced ERK2 activation [87]. Socodato and colleagues validated this Src-mediated effect, downstream of the canonical NO pathway, in regulating ERK2 phosphorylation using shRNA-mediated Src loss-of-function and retroviral-dependent Src gain-of-function in primary retinal neuronal cultures [87]. As a direct evidence for the importance of this concatenated signaling, it has been reported that cGMP/PKG/ERK pathway is a key signaling step in the expression of proteins involved in nNOS-dependent neuronal plasticity [115].

Furthermore, it has been shown that glutamate/AMPA/NOS/PKG/ERK was an upstream regulatory pathway for the transcription factor cAMP-responsive element binding protein (CREB) in cultured retinal cells [114]. Intriguingly, immunocytochemistry and fluorescence microscopy experiments demonstrated that glutamate and NO could stimulate CREB phosphorylation exclusively in Müller glia with no effect in retinal neurons [114]. These data were unexpected since neurons were the classical and well-established targets in coupling glutamatergic neurotransmission to CREB activation in the CNS. In subsequent experiments, the authors demonstrated that neuronal-derived NO could diffuse from neurons to reach the Müller glial cells and regulate the phosphorylation of CREB [114], indicating a direct interplay between neurons and Müller glial cells in coupling glutamate- induced NO release to CREB-mediated transcriptional activation.

In these experiments, Socodato and colleagues (2009) used both mixed neuron-glia cultures and purified glial cultures to measure glutamate-evoked NO release using a selective NO electrode. The authors documented that glutamate could only evoke NO release and CREB phosphorylation in neuron-containing cultures, while in purified glial cultures NO release induced by glutamate was not observed [114]. However, once reached the Müller glia, NO transduction relay promptly induced CREB phosphorylation since sGC and ERK2 were expressed in cultured Müller cells (Fig. 3). However, contrasting results from Riccio and colleagues indicated that NO could also trigger a cGMP-independent and S-nitrosylation-dependent CREB-DNA binding activity and CREB-regulated transcription in cortical neurons in the absence of CREB phosphorylation [116]. Later on, Riccio and associates characterized that BDNF-mediated NO production in cortical neurons could regulate HDAC2-DNA binding activity and consequent CREB-dependent promoter activation by an S-nitrosylation mechanism [117]. In that sense, it was shown that S-nitrosylation of HDAC2 at Cys 262 and 274 uncoupled this enzyme from the DNA, maintaining histone acetylation and promoter activity in BDNFinduced genes [117].

Although neuronal CREB activation is classically known to play important physiological roles within the brain, conclusive reports also suggested key signaling roles of CREB in glial cells. For instance, ATP and noradrenaline may cooperate to regulate the transcription of $b d n f$ gene in cortical astrocytes, which could directly influence activity-dependent synaptic plasticity in cortical cells [118]. Besides, it has also been shown that CREB could partially mediate a cGMP/PKG-dependent anti-apoptotic signal in R28 neuroglial progenitor cells [119], and that $\mathrm{NO} / \mathrm{Ca}^{2+}$-responsive CREB signaling pathway played an important role in regulating endoplasmic reticulum-related cell death in human glioma cells [120].

Therefore, it would be interesting to speculate that a cooperative signaling between neuronal-produced NO and glial CREB activation may orchestrate a development-based differentiation of Müller cell progenitors, since NO itself could directly inhibit glial proliferation through S-nitrosylation [110] while, in a cGMP/PKG/ERK2-dependent fashion, NO could trigger CREB-dependent transcription of genes related with cell differentiation, such as c-fos [114], and cell survival (Fig. 3).

\subsection{NO and Retinal Cell Death or Survival}

Within neuronal cells, NO may be generated postsynaptically through the activity of NMDA receptors, which couple activity-dependent excitatory neurotransmission to nNOS activation by the $\mathrm{Ca}^{2+} / \mathrm{CaM}$ complex. NO may also diffuse back into the presynaptic terminal and act as a retrograde messenger associated with synaptic strengthening and plasticity, a mechanism that plays an import role in long-term sensitization. Due to its chemical nature in biological systems, NO quickly diffuses through the lipid membrane, activating signaling cascades at different cellular compartments. NO is widely studied in biological systems including the 
CNS. However, its actions and signaling mechanisms with respect to the modulation of neuronal survival and death are still controversial. Literature data demonstrate that in several cases NO displays cytotoxic effects but in lesser cases it has been described as a neuroprotective agent.

Specifically in the retina, our group has long been interested in the effects of NO regarding the mechanistic regulation of neuronal cell survival and death. It has been shown that NO was a neurotoxic agent for retinal neurons when released from LPS-primed Müller glial cells [121]. In this scenario, neurons co-cultured with Müller cells derived from iNOS null animals were preserved even when glial cells were stimulated with LPS. The authors readily concluded that iNOS-produced NO mediated retinal neuronal loss [121]. Further on, the use either of a sGC inhibitor or a caspase inhibitor rescued this NO-induced cell death, while a peroxynitrite scavenger prevented this effect [121]. Additional evidence from iNOS knockout mice clearly suggested that in an in vivo model of retinopathy, NO generated from this pathway critically contributed for neuronal degeneration during the course of disease [122]. In a different report, it was shown that iNOS-mediated NO production, in an in vivo model of experimental autoimmune uveoretinitis, dramatically contributed to photoreceptor cell death [123]. An interesting finding however suggested that the cellular NO source within the retina in this in vivo paradigm were infiltrating monocytic cells and not resident retinal immune cells [123]. In line with this, anoxia-induced cultured retinal ganglion cell (RGC) loss was prevented by pharmacological blockade of NOS [124]. In another set of experiments, it was demonstrated that broad-spectrum NOS inhibitors could significantly delay optic nerve axotomy-induced RGC loss [125].

Furthermore, RGC are highly sensitive to NO in the absence of glial cells. In purified rat RGC cultures, NO promoted a dose-dependent increase in cell death, while in RGC co-cultured with Müller glial cells this effect was prevented [126]. NOS activity has also been claimed to play a prominent role in cell death during transient retinal ischemia in rats [127]. Injection of a NOS inhibitor alleviated the deleterious effects of ischemic insult in the photoreceptor layer [127]. In the mouse retina, nNOS-induced NO production and sGC activity has been demonstrated to participate in light-induced photoreceptor degeneration [128]. In that work, the authors documented that intense light stimulation increased $\mathrm{Ca}^{2+}$ dynamics in retinal cells, which could lead to nNOS activation and concomitant NO-induced photoreceptor apoptosis [128]. However, Donovan and colleagues (2001) found no direct evidence of a caspase-3-mediated apoptosis in this NO-induced neuronal loss in their in vivo paradigm of lightmediated retinal damage. In another report, it was demonstrated that albino rats also displayed a severe NOSdependent component in light-induced photoreceptor damage and retinal impairment [129]. In that report, the authors showed that inhibiting NOS with L-NAME rescued lightinduced photoreceptor loss, accompanied by a robust retinal gain of function [129].

In vivo injections of a NO donor (NOC-12 in this case) in rat eyes produced a robust cell death, mainly in the ganglion cell layer, which was also accompanied by a significant decrease of inner plexiform layer thickness [130]. Interestingly, injection of trophic factors such as CNTF, BDNF or erythropoietin completely prevented this NO-induced retinal damage $[130,131]$. In another set of experiments, it was demonstrated that NOS inhibition played a significant role both in high glucose and advanced glycation end products (AGEs)induced loss of cultured retinal cells [132, 133]. Furthermore, endothelin-1 has been shown to increase NO production in cultured retinal cells and this effect was directly associated with endothelin-1-mediated retinal neuronal death [134]. Besides, NOS blockade prevented cone photoreceptor degeneration in the rd-1 mouse model of retinitis pigmentosa [135]. Moreover, NO has been recently associated with TRPV-1-mediated retinal cell death in the mature rodent retina [136]. On the other hand, it was demonstrated that NO displayed an anti-apoptotic action upon neuronal precursor cells in the rat retina [137]. The authors used an in vitro system to demonstrate that endogenous NO release could protect cells in the retinal neuroblastic layer from anisomycininduced apoptosis [137]. Besides, using a diaphorase-based histochemical labeling, the authors concluded that NO exerted its neuroprotective role in developing retinal cells in a paracrine fashion (from the internal retina towards the neuroblastic layer) [137].

Our group characterized a paradigm of neuronal cell death induced by fresh medium re-feeding [83]. In 2007, using this same model of retinal neuronal death, we showed that the NO donor SNAP was capable of preventing this refeeding-induced cell loss [84]. Besides, release of NO from other donors like GSNO, or the increase of endogenous NO production in cultured neurons using L-Arg also abrogated neuronal death [84].

Many of the neurotoxic effects observed in retinal cells were associated with the capacity of NO in contributing to ROS generation. However, Mejía-García and Paes-deCarvalho in 2007 showed that the neuroprotection induced by $\mathrm{NO}$ in retinal neurons was completely dependent on sGC and cGMP accumulation [84]. Furthermore, the protective effect of NO on retinal neurons involved different protein kinases, as for example the PI3K/AKT and MEK/ERK pathways, since inhibiting both pathways NO-induced neuronal survival was prevented. Nonetheless, it is not possible to exclude the involvement of CREB in the survival mechanism mediated by NO since we also have demonstrated the regulation of CREB phosphorylation by NO as a consequence of excitatory signaling in retinal neurons [114], and CREB activity is likely to be involved in the developmental regulation of retinal cell survival [138]. However, in 2012, Socodato and colleagues published a work showing the involvement of $\mathrm{Ca}^{2+}$-permeable AMPA receptor activation in increasing apoptotic cell death in the retina by the downstream production of NO. It has been shown that activation of $\mathrm{Ca}^{2+}$-permeable AMPA receptors could activate nNOS, which in turn, via the sGC/PKG, increased the (activation of Src) tyrosine kinase, leading to retinal neuronal apoptosis (Fig. 3).

Interestingly, the regulation of Src activation by AMPA/$\mathrm{NO} / \mathrm{PKG}$ occurs in neurons [87], corroborating previous findings which indicate that neurons, but not Müller glial cells, in retinal cultures were capable of producing NO in response to glutamate stimulation. In that sense, it is sugges- 
tive that cultured neurons treated with glutamate could not activate a CREB-dependent neuroprotective pathway [114]. Therefore, due to excitotoxic stimulation of AMPA receptors, retinal neurons undergo nNOS-dependent apoptotic cell death, while Müller cells may upregulate CREB activation and were preserved from this NO-mediated cell damage (Fig. 3).

More recently, our group showed that glutamate, NMDA and the NO classical pathway is also involved in AKT phosphorylation at both Ser 473 and Thr 308 residues. This AKT phosphorylation was required to its translocation to neuronal cell nucleus in cultured retinal cells through a phosphatidylinositol 3' kinase (PI3K) pathway [143]. Recent findings indicate that this nuclear localization of AKT is related to important cellular functions such as proliferation [139] and neuronal differentiation [140]. In addition, increase in NO levels was linked with increased AKT phosphorylation and neuronal cell survival [141]. Along with AKT, it was also observed that inhibition of NOS decreases the phosphorylation of CREB, which may lead to neuronal damage [142]. Still, our previous findings showing that the survival of retinal neurons mediated by NO in retinal cultures is dependent on PI3K activity [84] prompted us to presume that AKT activation, and its consequent nuclear translocation, were responsible for the activation of transcription factors to consequently increase retinal neuronal survival (Fig. 3).

\section{CONCLUDING REMARKS}

In this review, we navigated through the deep sea represented by the signaling of NO in the developing retina. We hope we have convinced the reader that NO controls intricate neurochemical networks within retinal neuronal and glial cells and should be regarded as an essential atypical retinal messenger. The release and uptake of transmitter molecules, cellular proliferation and neuronal survival are fundamental aspects for proper development of nerve tissues and, based in solid literature background, we argue that NO is tightly correlated with such regulatory aspects in the developing retinal tissue. Overall, the understanding of NO actions, and its related downstream pathways, may shed light into the network of events modulating the development of the vertebrate retina either under normal or pathophysiological conditions that may culminate in the onset of retinal degenerative diseases.

\section{EPILOGUE}

Current effort is now being carried out to comprehend the concrete NO participation in the early retinal development. Preliminary data suggest that endogenous NO either can turn on or switch-off the pro-apoptotic program of developing retinal precursor cells in the early retina. Surprisingly, these effects rely exclusively on the activity of PKG-II during retinal development.

\section{CONFLICT OF INTEREST}

This work was supported by grants from CNPq, CAPES, FAPERJ and PRONEX/FAPERJ.

*CCP was a post-doctoral fellow from PNPD-CAPES; TGE and ID were recipients of student fellowships from CAPES. RPC was a research fellow from CNPq.
*The authors declare no conflict of interest.

\section{ACKNOWLEDGEMENT}

None declared.

\section{REFERENCES}

[1] Lindeman, V. In The formation of acetylcholine in the developing retina of the chick embryo. Fed. Proc., 1947; p. 153.

[2] Coulombre, A. J. Correlations of structural and biochemical changes in the developing retina of the chick. Am. J. Anat., 1955, 96 (1), 153-189.

[3] Fujita, S.; Horii, M. Analysis of cytogenesis in chick retina by tritiated thymidine autoradiography. Arch. Histol .Jpn., 1963, 23, 359-366.

[4] Witkovsky, P. An ontogenetic study of retinal function in the chick. Vis. Res., 1963, 3 (7), 341-355.

[5] Moscona, M.; Moscona, A. Inhibition of adhesiveness and aggregation of dissociated cells by inhibitors of protein and rna synthesis. Science, 1963, 142 (3595), 1070-1071.

[6] Kirk, D. L.; Moscona, A. Synthesis of experimentally induced glutamine synthetase (glutamotransferase activity) in embryonic chick retina in vitro. Dev. Biol., 1963, 8 (3), 341-357.

[7] Moscona, A.; Kirk, D. L. Control of glutamine synthetase in the embryonic retina in vitro. Science, 1965, 148 (3669), 519-521.

[8] Moscona, A.; Piddington, R. Stimulation by hydrocortisone of premature changes in the developmental pattern of glutamine synthetase in embryonic retina. Biochim. Biophys. Acta., 1966, 121 (2), 409-411.

[9] Sheffield, J.; Moscona, A. Early stages in the reaggregation of embryonic chick neural retina cells. Exp. Cell. Res., 1969, 57 (2), 462-466.

[10] Sheffield, J. B.; Moscona, A. Electron microscopic analysis of aggregation of embryonic cells: the structure and differentiation of aggregates of neural retina cells. Dev. Biol., 1970, 23 (1), 36-61.

[11] Morris, J. E.; Moscona, A. Induction of glutamine synthetase in embryonic retina: its dependence on cell interactions. Science, 1970, 167 (3926), 1736-1738.

[12] Morris, J. E.; Moscona, A. The induction of glutamine synthetase in cell aggregates of embryonic neural retina: correlations with differentiation and multicellular organization. Dev. Biol., 1971, 25 (3), 420-444.

[13] Tunnicliff, G.; Cho, Y.; Martin, R. Kinetic properties of the GABA uptake system in cultures of chick retina. Neurobiology. 1974, 4 (1), 38-42.

[14] Tunnicliff, G.; Firneisz, G.; Ngo, T.; Martin, R. Developmental changes in the kinetics of gamma-aminobutyric acid transport by chick retina. J. Neurochem., 1975, 25 (5), 649-652.

[15] Kahn, A. An autoradiographic analysis of the time of appearance of neurons in the developing chick neural retina. Dev. Biol., 1974, 38 (1), 30-40.

[16] Hughes, W. F.; LaVelle, A. On the synaptogenic sequence in the chick retina. Anat. Rec., 1974, 179 (3), 297-301.

[17] Vogel, Z.; Daniels, M. P.; Nirenberg, M. Synapse and acetylcholine receptor synthesis by neurons dissociated from retina. Proc. Natl. Acad. Sci. USA, 1976, 73 (7), 2370-2374.

[18] Yazulla, S.; Brecha, N. Binding and uptake of the GABA analogue, $3 \mathrm{H}$-muscimol, in the retinas of goldfish and chicken. Invest. Ophthalmol. Vis. Sci., 1980, 19 (12), 1415-1426.

[19] López-Colomé, A. High-affinity binding of l-glutamate to chick retinal membranes. Neurochem. Res., 1981, 6 (9), 1019-1033.

[20] de Mello, F. The ontogeny of dopamine-dependent increase of adenosine 3',5'-cyclic monophosphate in the chick retina. J. Neurochem., 1978, 31 (4), 1049-1053.

[21] de Mello, M.; Ventura, A.; Paes de Carvalho, R.; Klein, W.; de Mello, F. Regulation of dopamine-and adenosine-dependent adenylate cyclase systems of chicken embryo retina cells in culture. Proc. Natl. Acad. Sci. USA, 1982, 79 (18), 5708-5712.

[22] Paes-de-Carvalho, R.; de Mello, F. Adenosine-elicited accumulation of adenosine 3', 5'-cyclic monophosphate in the chick embryo retina. J. Neurochem., 1982, 38 (2), 493-500.

[23] Cossenza, M.; Cadilhe, D. V.; Coutinho, R. N.; Paes-de-Carvalho, R. Inhibition of protein synthesis by activation of NMDA receptors 
in cultured retinal cells: a new mechanism for the regulation of nitric oxide production. J. Neurochem., 2006, 97 (5), 1481.

[24] Paes-de-Carvalho, R.; de Mello, F. Expression of A1 adenosine receptors modulating dopamine-dependent cyclic AMP accumulation in the chick embryo retina. J. Neurochem., 1985, 44 (3), 845-851.

[25] Paes-de-Carvalho, R.; Braas, K. M.; Snyder, S. H.; Adler, R. Analysis of adenosine immunoreactivity, uptake, and release in purified cultures of developing chick embryo retinal neurons and photoreceptors. J. Neurochem., 1990, 55 (5), 1603-1611.

[26] Campochiaro, P.; Ferkany, J. W.; Coyle, J. T. The dissociation of evoked release of [3H]-GABA and of endogenous GABA from chickretina in vitro. Exp. Eye. Res., 1984, 39 (3), 299-305.

[27] Campochiaro, P.; Ferkany, J. W.; Coyle, J. T. Excitatory amino acid analogs evoke release of endogenous amino acids and acetyl choline from chick retina in vitro. Vis. Res., 1985, 25 (10), 13751386.

[28] Paes-de-Carvalho, R.; Dias, B. V.; Martins, R. A.; Pereira, M. R.; Portugal, C. C.; Lanfredi, C. Activation of glutamate receptors promotes a calcium-dependent and transporter-mediated release of purines in cultured avian retinal cells: possible involvement of calcium/calmodulin-dependent protein kinase II. Neurochem. Int., 2005, 46 (6), 441-451.

[29] Paes-de-Carvalho, R.; Braas, K. M.; Adler, R.; Snyder, S. H. Developmental regulation of adenosine A1 receptors, uptake sites and endogenous adenosine in the chick retina. Brain. Res. Dev. Brain. Res., 1992, 70 (1), 87-95.

[30] Pereira, M. R.; Hang, V. R.; Vardiero, E.; De Mello, F. G.; Paesde-Carvalho, R. Modulation of A1 adenosine receptor expression by cell aggregation and long-term activation of A2a receptors in cultures of avian retinal cells: involvement of the cyclic AMP/PKA pathway. J. Neurochem., 2010, 113 (3), 661-673.

[31] Brito, R.; Pereira, M. R.; Paes-de-Carvalho, R.; Calaza, K. D. C. Expression of $\mathrm{A} 1$ adenosine receptors in the developing avian retina: in vivo modulation by A2A receptors and endogenous adenosine. J Neurochem., 2012, 123 (2): 239-249.

[32] Garthwaite, J.; Boulton, C. Nitric oxide signaling in the central nervous system. Ann. Rev. Physiol., 1995, 57 (1), 683-706.

[33] Garthwaite, J.; Charles, S. L.; Chess-Williams, R. Endotheliumderived relaxing factor release on activation of NMDA receptors suggests role as intercellular messenger in the brain. Nature, 1988, 336, 385-388.

[34] Garthwaite, J.; Garthwaite, G. Cellular origins of cyclic GMP responses to excitatory amino acid receptor agonists in rat cerebellum in vitro. J. Neurochem., 1987, 48 (1), 29-39.

[35] Knowles, R. G.; Palacios, M.; Palmer, R.; Moncada, S. Formation of nitric oxide from L-arginine in the central nervous system: a transduction mechanism for stimulation of the soluble guanylate cyclase. Proc. Natl. Acad. Sci. US A, 1989, 86 (13), 5159-5162.

[36] Bredt, D.; Snyder, S. Isolation of nitric oxide synthetase, a calmodulin-requiring enzyme. Proc. Natl. Acad. Sci. USA, 1990, 87 (2), 682-685.

[37] Bredt, D. S.; Glatt, C. E.; Hwang, P. M.; Fotuhi, M.; Dawson, T. M.; Snyder, S. H. Nitric oxide synthase protein and mRNA are discretely localized in neuronal populations of the mammalian CNS together with NADPH diaphorase. Neuron, 1991, 7 (4), 615.

[38] Bredt, D. S.; Hwang, P. M.; Snyder, S. H. Localization of nitric oxide synthase indicating a neural role for nitric oxide. Nature, 1990, 347 (6295), 768.

[39] Venturini, C.; Knowles, R.; Palmer, R.; Moncada, S. Synthesis of nitric oxide in the bovine retina. Biochem. Biophys. Res. Commun., 1991, 180 (2), 920-925.

[40] Shiells, R.; Falk, G. Retinal on-bipolar cells contain a nitric oxidesensitive guanylate cyclase. Neuroreport., 1992, 3 (10), 845-848.

[41] Hope, B. T.; Michael, G. J.; Knigge, K. M.; Vincent, S. R. Neuronal NADPH diaphorase is a nitric oxide synthase. Proc. Natl. Acad. Sci., USA 1991, 88 (7), 2811-2814.

[42] Pasqualotto, B. A.; Hope, B. T.; Vincent, S. R. Citrulline in the rat brain: immunohistochemistry and coexistence with NADPHdiaphorase. Neurosci. Lett., 1991, 128 (2), 155-160.

[43] Gally, J. A.; Montague, P. R.; Reeke Jr, G. N.; Edelman, G. M. The NO hypothesis: possible effects of a short-lived, rapidly diffusible signal in the development and function of the nervous system. Proc. Natl. Acad. Sci., USA 1990, 87 (9), 3547-3551.

[44] Southam, E.; East, S.; Garthwaite, J. Excitatory amino acid receptors coupled to the nitric oxide/cyclic GMP pathway in rat cerebellum during development. J. Neurochem., 1991, 56 (6), 2072-2081.

[45] Brüning , G. NADPH-diaphorase histochemistry in the postnatal mouse cerebellum suggests specific developmental functions for nitric oxide. J. Neurosci. Res., 1993, 36 (5), 580-587.

[46] Kalb, R.; Agostini, J. Molecular evidence for nitric oxide-mediated motor neuron development. Neuroscience., 1993, 57 (1), 1-8.

[47] Hess, D. T.; Patterson, S. I.; Smith, D. S.; Skene, J. P. Neuronal growth cone collapse and inhibition of protein fatty acylation by nitric oxide. Nature, 1993, 366 (6455), 562-565.

[48] Wu, H. H.; Williams, C. V.; McLoon, S. C. Involvement of nitric oxide in the elimination of a transient retinotectal projection in development. Science, 1994, 265 (5178), 1593-1596.

[49] Kuzin, B.; Roberts, I.; Peunova, N.; Enikolopov, G. Nitric oxide regulates cell proliferation during Drosophila development. Cell 1996, 87 (4), 639-649.

[50] Peunova, N.; Enikolopov, G. Amplification of calcium-induced gene transcription by nitric oxide in neuronal cells. Nature, 1993, 364 (6436), 450-453.

[51] Peunova, N.; Enikolopov, G. Nitric oxide triggers a switch to growth arrest during differentiation of neuronal cells. Nature, 1995, 375 (6526), 68-73.

[52] Cech, T. R.; Bennett, D.; Jasny, B.; Kelner, K. L.; Miller, L. J.; Szuromi, P. D.; Voss, D. F.; Kiberstis, P. A.; Parks, S.; Ray, L. B. The molecule of the year. Science, 1992, 258, 1861.

[53] Thomas, E.; Pearse, A. The fine localization of dehydrogenases in the nervous system. Z. Zellfor. Microsk. Anat. Histochem., 1961, 2 (4), 266-282.

[54] Elphick, M. R. Localization of nitric oxide synthase using NADPH diaphorase histochemistry. In: Methods Mol. Biol., Springer: USA 1997; pp. 53-158.

[55] Paes-de-Carvalho, R.; De Faria, M.; Do Nascimento, J.; Hokoc, J. Development of NADPH Diaphorase in the Avian Retina: Regulation by Calcium Ions and Relation to Nitric Oxide Synthase. J. Neurochem., 1996, 67 (3), 1063-1071.

[56] de Faria, M.; do Nascimento, J.; Paes-de-Carvalho, R. Biochemical characterization of NADPH-diaphorase in the chick embryo retina: stimulation by calcium ions and inhibition by arginine analogs. Braz. J. Med. Biol. Res., 1995, 28 (2), 252-255.

[57] Yamamoto, R.; Bredt, D.; Snyder, S.; Stone, R. The localization of nitric oxide synthase in the rat eye and related cranial ganglia. Neuroscience, 1993, 54 (1), 189-200.

[58] Huxlin, K. R. NADPH-diaphorase expression in neurons and glia of the normal adult rat retina. Brain. Res., 1995, 692 (1), 195-206.

[59] Perez, M.; Larsson, B.; Alm, P.; Andersson, K.-E.; Ehinger, B. Localisation of neuronal nitric oxide synthase-immunoreactivity in rat and rabbit retinas. Exp. Brain. Res., 1995, 104 (2), 207-217.

[60] Mitrofanis, J.; Robinson, S. R.; Ashwell, K. Development of catecholaminergic, indoleamine-accumulating and NADPH diaphorase amacrine cells in rabbit retinae. J. Comp. Neurobiol., 1992, 319 (4), 560-585.

[61] Koistinaho, J.; Swanson, R.; De Vente, J.; Sagar, S. NADPHdiaphorase (nitric oxide synthase)-reactive amacrine cells of rabbit retina: putative target cells and stimulation by light. Neuroscience, 1993, 57 (3), 587-597.

[62] Sandell, J. NADPH diaphorase cells in the mammalian inner retina. J. Comp. Neurobiol., 1985, 238 (4), 466-472.

[63] Deguchi, T.; Yoshioka, M. L-Arginine identified as an endogenous activator for soluble guanylate cyclase from neuroblastoma cells. $J$. Biol. Chem., 1982, 257 (17), 10147-10151.

[64] Katsuki, S.; Arnold, W.; Mittal, C.; Murad, F. Stimulation of guanylate cyclase by sodium nitroprusside, nitroglycerin and nitric oxide in various tissue preparations and comparison to the effects of sodium azide and hydroxylamine. J. Cyclic. Nucleotide. Res., 1977, 3 (1), 23.

[65] Arnold, W. P.; Mittal, C. K.; Katsuki, S.; Murad, F. Nitric oxide activates guanylate cyclase and increases guanosine 3',5-cyclic monophosphate levels in various tissue preparations. Proc. Natl. Acad. Sci., US A 1977, 74 (8), 3203-3207.

[66] Krebs, H. A.; Henseleit, K. Untersuchungen uber die Harnstoffbildung im Tierkörper. Hope Seyler Z. Physiol. Chem., 1932, 210 (1-2), 33-66.

[67] Jones, M. E.; Anderson, A. D.; Anderson, C.; Hodes, S. Citrulline synthesis in rat tissues. Arch. Biochem. Biophys., 1961, 95 (3), 499-507. 
[68] Ientile, R.; Malecka, B.; Picciurro, V.; Naso, A.; Pedale, S.; Macaione, $\mathrm{S}$. Nitric oxide synthase in chick embryo retina during development. FEBS Lett., 1996, 379 (1), 82-84.

[69] Olken, N. M.; Marletta, M. A. NG-methyl-L-arginine functions as an alternate substrate and mechanism-based inhibitor of nitric oxide synthase. Biochemist, 1993, 32 (37), 9677-9685.

[70] Cossenza, M.; Paes-de-Carvalho, R. L-arginine uptake and release by cultured avian retinal cells: differential cellular localization in relation to nitric oxide synthase. J. Neurochem., 2000, 74 (5), 1885-1894.

[71] Vega-Agapito, V.; Almeida, A.; Heales, S. J.; Medina, J. M.; Bolaños, J. P. Peroxynitrite anion stimulates arginine release from cultured rat astrocytes. J. Neurochem., 1999, 73 (4), 1446-1452.

[72] Grima, G.; Benz, B.; Do, K. Q. Glutamate-induced release of the nitric oxide precursor, arginine, from glial cells. Eur J. Neurosci., 1997, 9 (11), 2248-2258.

[73] Grima, G.; Cuénod, M.; Pfeiffer, S.; Mayer, B.; Do, K. Q. Arginine availability controls the $\mathrm{N}$-methyl-D-aspartate-induced nitric oxide synthesis: involvement of a glial-neuronal arginine transfer. $J$. Neurochem., 1998, 71 (5), 2139-2144.

[74] Arnt-Ramos, L.; O'Brien, W.; Vincent, S. Immunohistochemical localization of argininosuccinate synthetase in the rat brain in relation to nitric oxide synthase-containing neurons. Neuroscience, 1992, 51 (4), 773-789.

[75] Aoki, E.; Semba, R.; Mikoshiba, K.; Kashiwamata, S. Predominant localization in glial cells of free l-arginine. Immunocytochemical evidence. Brain. Res., 1991, 547 (2), 190-192.

[76] Nakamura, H.; Saheki, T.; Ichiki, H.; Nakata, K.; Nakagawa, S. Immunocytochemical localization of argininosuccinate synthetase in the rat brain. J. Comp. Neurobiol., 1991, 312 (4), 652-679.

[77] Pow, D. V. Immunocytochemical evidence for a glial localisation of arginine, and a neuronal localisation of citrulline in the rat neurohypophysis: implications for nitrergic transmission. Neurosci. Lett., 1994, 181 (1), 141-144.

[78] Vincent, S.; Kimura, H. Histochemical mapping of nitric oxide synthase in the rat brain. Neuroscience, 1992, 46 (4), 755-784.

[79] Griess, P. Bemerkungen zu der Abhandlung der HH. Weselsky und Benedikt „Ueber einige Azoverbindungen”. Ber. Dtsch. Chem. Ges., 1879, 12 (1), 426-428.

[80] Tsikas, D. Analysis of nitrite and nitrate in biological fluids by assays based on the Griess reaction: appraisal of the Griess reaction in the L-arginine/nitric oxide area of research. Chromatogr. B. Analyt. Technol. Biomed. Life. Sci., 2007, 851 (1-2), 51-70.

[81] Green, L. C.; Wagner, D. A.; Glogowski, J.; Skipper, P. L.; Wishnok, J. S.; Tannenbaum, S. R. Analysis of nitrate, nitrite, and [15N]nitrate in biological fluids. Anal. Biochem., 1982, 126 (1), 131-138.

[82] Florquin, S.; Amraoui, Z.; Dubois, C.; Decuyper, J.; Goldman, M. The protective role of endogenously synthesized nitric oxide in staphylococcal enterotoxin B-induced shock in mice. J. Exp. Med., 1994, 180 (3), 1153-1158.

[83] Paes-de-Carvalho, R.; Maia, G.; Ferreira, J. Adenosine regulates the survival of avian retinal neurons and photoreceptors in culture. Neurochem. Res., 2003, 28 (10), 1583-1590.

[84] Mejía-García, T.; Paes-de-Carvalho, R. Nitric oxide regulates cell survival in purified cultures of avian retinal neurons: involvement of multiple transduction pathways. J. Neurochem., 2007, 100 (2), 382-394.

[85] Kojima, H.; Nakatsubo, N.; Kikuchi, K.; Kawahara, S.; Kirino, Y.; Nagoshi, H.; Hirata, Y.; Nagano, T. Detection and imaging of nitric oxide with novel fluorescent indicators: diaminofluoresceins. Anal. Chem., 1998, 70 (13), 2446-2453.

[86] Kojima, H.; Urano, Y.; Kikuchi, K.; Higuchi, T.; Hirata, Y.; Nagano, T. Fluorescent indicators for imaging nitric oxide production. Angew. Chem. Int. Ed. Engl., 1999, 38 (21), 32093212.

[87] Socodato, R.; Santiago, F. N.; Portugal, C. C.; Domingues, A. F.; Santiago, A. R.; Relvas, J. B.; Ambrósio, A. F.; Paes-de-Carvalho, R. Calcium-permeable $\quad \alpha$-Amino-3-hydroxy-5-methyl-4isoxazolepropionic Acid Receptors Trigger Neuronal Nitric-oxide Synthase Activation to Promote Nerve Cell Death in an Src Kinasedependent Fashion. J. Biol. Chem., 2012, 287 (46), 38680-38694.

[88] Ientile, R.; Picciurro, V.; Pedale, S.; Nucci, C.; Malecka, B.; Nisticò, G.; Macaione, S. Nitric oxide enhances amino acid release from immature chick embryo retina. Neurosci. Lett., 1996, 219 (2), 79-82.
[89] Maggesissi, R.; Gardino, P.; Guimarães-Souza, E.; Paes-deCarvalho, R.; Silva, R.; Calaza, K. Modulation of GABA release by nitric oxide in the chick retina: different effects of nitric oxide depending on the cell population. Vis. Res., 2009, 49 (20), 24942502.

[90] Portugal, C. C.; da Encarnação, T. G.; Socodato, R.; Moreira, S. R.; Brudzewsky, D.; Ambrósio, A. F.; Paes-de-Carvalho, R. Nitric Oxide Modulates Sodium Vitamin C Transporter 2 (SVCT-2) Protein Expression via Protein Kinase G (PKG) and Nuclear Factor-kappaB (NF-kB). J. Biol. Chem., 2012, 287 (6), 3860-3872.

[91] Ientile, R.; Pedale, S.; Picciurro, V.; Macaione, V.; Fabiano, C.; Macaione, S. Nitric oxide mediates NMDA-evoked [3H] GABA release from chick retina cells. FEBS. Lett., 1997, 417 (3), 345348.

[92] Nascimento, J. L. M.; Mello, F. G. Induced release of gammaaminobutyric acid by a carrier-mediated, high-affinity uptake of Lglutamate in cultured chick retina cells. J. Neurochem., 1985, 45 (6), 1820-1827.

[93] Yu, D.; Eldred, W. D. Nitric oxide stimulates gamma aminobutyric acid release and inhibits glycine release in retina. J. Comp. Neurol., 2005, 483 (3), 278-291.

[94] Neal, M.; Cunningham, J.; Matthews, K. Nitric oxide enhancement of cholinergic amacrine activity by inhibition of glycine release. Invest. Ophthalmol. Vis. Sci., 1997, 38 (8), 1634-1639.

[95] Okada, M.; Osumi, Y.; Okuma, Y.; Ueno, H. Nitric oxide inhibits the release of acetylcholine in the isolated retina. Graefes. Arch. Clin. Exp. Ophthalmol., 2001, 239 (3), 217-221.

[96] Bugnon, O.; Schaad, N. C.; Schorderet, M. Nitric oxide modulates endogenous dopamine release in bovine retina. Neuroreport, 1994, 5 (4), 401-404.

[97] Djamgoz, M.; Cunningham, J.; Davenport, S.; Neal, M. Nitric oxide inhibits depolarization-induced release of endogenous dopamine in the rabbit retina. Neurosci. Lett., 1995, 198 (1), 33-36.

[98] Pottek, M.; Schultz, K.; Weiler, R. Effects of nitric oxide on the horizontal cell network and dopamine release in the carp retina. Vis. Res., 1997, 37 (9), 1091-1102.

[99] Neal, M. J.; Cunningham, J. R.; Matthews, K. L. Release of endogenous ascorbic acid preserves extracellular dopamine in the mammalian retina. Invest. Ophthalmol. Vis. Sci., 1999, 40 (12), 2983-2987.

[100] Rebec, G. V.; Pierce, R. A vitamin as neuromodulator: ascorbate release into the extracellular fluid of the brain regulates dopaminergic and glutamatergic transmission. Prog. Neurobiol., 1994, 43 (6), 537-565.

[101] Qiu, S.; Li, L.; Weeber, E. J.; May, J. M. Ascorbate transport by primary cultured neurons and its role in neuronal function and protection against excitotoxicity. J. Neurosci. Res., 2007, 85 (5), 1046-1056

[102] Lai, Y.-L.; Fong, D.; Lam, K.-W.; Wang, H.-M.; Tsin, A. T. Distribution of ascorbate in the retina, subretinal fluid and pigment epithelium. Curr. Eye. Res., 1986, 5 (12), 933-938.

[103] Lam, K.-W.; Zwaan, J.; Garcia, A.; Shields, C. Detection of ascorbic acid in the eye of the early chicken embryo by silver staining. Exp. Eye. Res., 1993, 56 (5), 601-604.

[104] Fan, S. F.; Yazulla, S. Suppression of voltage-dependent K+ currents in retinal bipolar cells by ascorbate. Vis. Neurosci.,1999, $16(1), 141-148$

[105] Yazulla, S. Evoked efflux of [3H] GABA from goldfish retina in the dark. Brain. Res., 1985, 325 (1-2), 171-180.

[106] Daruwala, R.; Song, J.; Koh, W. S.; Rumsey, S. C.; Levine, M. Cloning and functional characterization of the human sodiumdependent vitamin C transporters hSVCT1 and hSVCT2. FEBS. Lett., 1999, 460 (3), 480-484.

[107] Tsukaguchi, H.; Tokui, T.; MacKenzie, B.; Berger, U. V.; Chen, X. Z.; Wang, Y.; Brubaker, R. F.; Hediger, M. A. A family of mammalian $\mathrm{Na}+-$ dependent L-ascorbic acid transporters. Nature, 1999, 399, 70-75.

[108] Portugal, C. C.; Miya, V. S.; Calaza, K. C.; Santos, R. A. M.; Paesde-Carvalho, R. Glutamate receptors modulate sodium-dependent and calcium-independent vitamin C bidirectional transport in cultured avian retinal cells. J. Neurochem., 2009, 108 (2), 507-520.

[109] Savini, I.; Rossi, A.; Pierro, C.; Avigliano, L.; Catani, M. SVCT1 and SVCT2: key proteins for vitamin C uptake. Amino. Acids, 2008, 34 (3), 347-355.

[110] Magalhães, C. R.; Socodato, R. E. S.; Paes-de-Carvalho, R. Nitric oxide regulates the proliferation of chick embryo retina cells by a 
cyclic GMP-independent mechanism. Int. J. Dev. Neurosci., 2006, 24 (1), 53-60.

[111] Batista, W. L.; Ogata, F. T.; Curcio, M. F.; Miguel, R. B.; Arai, R. J.; Matsuo, A. L.; Moraes, M. S.; Stern, A. I.; Monteiro, H. P. Snitrosoglutathione and endothelial nitric oxide synthase-derived nitric oxide regulate compartmentalized Ras s-nitrosylation and stimulate cell proliferation. Antioxid. Redox. Signal., 2013, 18(8); 221-238.

[112] Bauer, P. M.; Fukuto, J. M.; Buga, G. M.; Pegg, A. E.; Ignarro, L. J. Nitric oxide inhibits ornithine decarboxylase by S-nitrosylation. Biochem. Biophys. Res. Commun., 1999, 262 (2), 355-358.

[113] Sanches, G.; Alencar, L. S. d.; Ventura, A. L. M. ATP induces proliferation of retinal cells in culture via activation of PKC and extracellular signal-regulated kinase cascade. Int. J. Dev. Neurosci., 2002, 20 (1), 21-27.

[114] Socodato, R. E. S.; Magalhães, C. R.; Paes-de-Carvalho, R. Glutamate and nitric oxide modulate ERK and CREB phosphorylation in the avian retina: evidence for direct signaling from neurons to Müller glial cells. J. Neurochem., 2009, 108 (2), 417-429.

[115] Gallo, E. F.; Iadecola, C. Neuronal nitric oxide contributes to neuroplasticity-associated protein expression through cGMP, protein kinase $\mathrm{G}$, and extracellular signal-regulated kinase. $J$. Neurosci., 2011, 31 (19), 6947-6955.

[116] Riccio, A.; Alvania, R. S.; Lonze, B. E.; Ramanan, N.; Kim, T.; Huang, Y.; Dawson, T. M.; Snyder, S. H.; Ginty, D. D. A nitric oxide signaling pathway controls CREB-mediated gene expression in neurons. Mol. Cell., 2006, 21 (2), 283-294.

[117] Nott, A.; Watson, P. M.; Robinson, J. D.; Crepaldi, L.; Riccio, A. S-Nitrosylation of histone deacetylase 2 induces chromatin remodelling in neurons. Nature, 2008, 455 (7211), 411-415.

[118] Carriba, P.; Pardo, L.; Parra-Damas, A.; Lichtenstein, M. P.; Saura, C. A.; Pujol, A.; Masgrau, R.; Galea, E. ATP and noradrenaline activate CREB in astrocytes via noncanonical $\mathrm{Ca} 2+$ and cyclic AMP independent pathways. Glia, 2012, 60 (9), 1330-1344.

[119] Nagai-Kusuhara, A.; Nakamura, M.; Mukuno, H.; Kanamori, A.; Negi, A.; Seigel, G. M. cAMP-responsive element binding protein mediates a cGMP/protein kinase G-dependent anti-apoptotic signal induced by nitric oxide in retinal neuro-glial progenitor cells. Exp. Eye. Res., 2007, 84 (1), 152-162.

[120] Kim, Y. H.; Joo, H. S.; Kim, D.-S. Nitric oxide induction of IRE1alpha-dependent CREB phosphorylation in human glioma cells. Nitric Oxide, 2010, 23 (2), 112-120.

[121] Goureau, O.; Régnier-Ricard, F.; Courtois, Y. Requirement for nitric oxide in retinal neuronal cell death induced by activated Müller glial cells. J. Neurochem., 1999, 72 (6), 2506-2515.

[122] Sennlaub, F.; Courtois, Y.; Goureau, O. Inducible nitric oxide synthase mediates retinal apoptosis in ischemic proliferative retinopathy. J. Neurosci., 2002, 22 (10), 3987-3993.

[123] Liversidge, J.; Dick, A.; Gordon, S. Nitric oxide mediates apoptosis through formation of peroxynitrite and Fas/Fas-ligand interactions in experimental autoimmune uveitis. Am. J. Pathols., 2002, 160 (3), 905-916.

[124] Morgan, J.; Caprioli, J.; Koseki, Y. Nitric oxide mediates excitotoxic and anoxic damage in rat retinal ganglion cells cocultured with astroglia. Arch. Ophthalmol.,1999, 117 (11), 15241529.

[125] Koeberle, P. D.; Ball, A. K. Nitric oxide synthase inhibition delays axonal degeneration and promotes the survival of axotomized retinal ganglion cells. Exp. Neurol., 1999, 158 (2), 366-381.

[126] Kawasaki, A.; Otori, Y.; Barnstable, C. J. Müller cell protection of rat retinal ganglion cells from glutamate and nitric oxide neurotoxicity. Invest. Ophthalmol. Vis. Sci., 2000, 41 (11), 34443450.
[127] Ju, W.-K.; Kim, K.-Y.; Park, S.-J.; Park, D.-K.; Park, C.-B.; Oh, S.J.; Chung, J.-W.; Chun, M.-H. Nitric oxide is involved in sustained and delayed cell death of rat retina following transient ischemia. Brain. Res., 2000, 881 (2), 231-236.

[128] Donovan, M.; Carmody, R. Ã. J.; Cotter, T. G. Light-induced photoreceptor apoptosis in vivo requires neuronal nitric-oxide synthase and guanylate cyclase activity and is caspase-3independent. J. Biol. Chem., 2001, 276 (25), 23000-23008.

[129] Káldi, I.; Dittmar, M.; Pierce, P.; Anderson, R. E. L-NAME protects against acute light damage in albino rats, but not against retinal degeneration in $\mathrm{P} 23 \mathrm{H}$ and S334ter transgenic rats. Exp. Eye. Res., 2003, 76 (4), 453-461.

[130] Takahata, K.; Katsuki, H.; Kume, T.; Nakata, D.; Ito, K.; Muraoka, S.; Yoneda, F.; Kashii, S.; Honda, Y.; Akaike, A. Retinal neuronal death induced by intraocular administration of a nitric oxide donor and its rescue by neurotrophic factors in rats. Invest. Ophthalmol. Vis. Sci., 2003, 44 (4), 1760-1766.

[131] Yamasaki, M.; Mishima, H. K.; Yamashita, H.; Kashiwagi, K.; Murata, K.; Minamoto, A.; Inaba, T. Neuroprotective effects of erythropoietin on glutamate and nitric oxide toxicity in primary cultured retinal ganglion cells. Brain. Res., 2005, 1050 (1), 15-26.

[132] Layton, C.; Wood, J.; Chidlow, G.; Osborne, N. Neuronal death in primary retinal cultures is related to nitric oxide production, and is inhibited by erythropoietin in a glucose, Äêsensitive manner. $J$. Neurochem., 2004, 92 (3), 487-493.

[133] Kobayashi, T.; Oku, H.; Komori, A.; Okuno, T.; Kojima, S.; Obayashi, H.; Sugiyama, T.; Hasegawa, G.; Fukui, M.; Nakamura, $\mathrm{N}$. Advanced glycation end products induce death of retinal neurons via activation of nitric oxide synthase. Exp. Eye. Res. 2005, 81 (6), 647-654

[134] Oku, H.; Fukuhara, M.; Komori, A.; Okuno, T.; Sugiyama, T.; Ikeda, T. Endothelin-1 (ET-1) causes death of retinal neurons through activation of nitric oxide synthase (NOS) and production of superoxide anion. Exp. Eye. Res., 2008, 86 (1), 118-130.

[135] Komeima, K.; Usui, S.; Shen, J.; Rogers, B. S.; Campochiaro, P. A. Blockade of neuronal nitric oxide synthase reduces cone cell death in a model of retinitis pigmentosa. Free. Rad. Biol. Med., 2008, 45 (6), 905-912.

[136] Leonelli, M.; Martins, D. O.; Britto, L. R. Retinal Cell Death Induced by TRPV1 Activation Involves NMDA Signaling and Upregulation of Nitric Oxide Synthases. Cell. Mol. Neurobiol., 2013, 33 (3), 1-14.

[137] Guimarães, C. A.; Assreuy, J.; Linden, R. Paracrine neuroprotective effect of nitric oxide in the developing retina. $J$. Neurochem., 2001, 76 (4), 1233-1241.

[138] Socodato, R.; Brito, R.; Calaza, K. C.; Paes de Carvalho, R. Developmental regulation of neuronal survival by adenosine in the in vitro and in vivo avian retina depends on a shift of signaling pathways leading to CREB phosphorylation or dephosphorylation. J. Neurochem., 2011, 116 (2), 227-239.

[139] Ornelas, I. M.; Silva, T. M.; Fragel-Madeira, L.; Ventura, A. L. M. Inhibition of PI3K/Akt Pathway Impairs G2/M Transition of Cell Cycle in Late Developing Progenitors of the Avian Embryo Retina. PLOS ONE, 2013, 8 (1), e53517.

[140] Park, J.; Lee, S.; Lee, K.; Ahn, J. Nuclear Akt promotes neurite outgrowth in the early stage of neuritogenesis. BMB Rep., 2012, 45 (9), 521-525.

[141] Ciani, E.; Virgili, M.; Contestabile, A. Akt pathway mediates a cGMP-dependent survival role of nitric oxide in cerebellar granule neurones. J. Neurochem., 2002, 81 (2), 218-228.

[142] Ciani, E.; Guidi, S.; Della Valle, G.; Perini, G.; Bartesaghi, R.; Contestabile, A. Nitric oxide protects neuroblastoma cells from apoptosis induced by serum deprivation through cAMP-response element-binding protein (CREB) activation. J. Biol. Chem., 2002, 277 (51), 49896-49902. 